

\title{
Family, Schools, or Culture: What Explains Differences in U.S. Student Achievement Across Ethnic Groups on PISA 2012?
}

\author{
Theodore R. Breton* \\ December 17, 2017
}

\begin{abstract}
U.S. students in different ethnic groups have very different average scores on the PISA 2012 mathematics and reading tests, with Blacks and Hispanics showing negative gaps relative to White students and Asians showing a positive gap. I investigate whether a student's family characteristics or the school attended can explain these differences. I find that Hispanic parents' low average education explains the largest share of the Hispanic achievement gap. In contrast, most of the larger negative gap for Blacks and the positive gap for Asians cannot be explained by family characteristics or the school they attend. Attendance at "bad" schools explains relatively little of the negative gaps, but Black students' mathematics scores are substantially lower when they compose more than 50\% of the class, which is not the case for Hispanic students. This evidence suggests that ethnic group culture is an important cause of Black and Asian student achievement gaps.
\end{abstract}

Key words: Cognitive skills; ethnic groups; family characteristics; schools; culture JEL Codes: $121 ; \mathrm{J} 24$

*Universidad EAFIT, Carrera 49\#7 Sur-50, avenida Las Vegas, Medellin, Colombia ted.breton@gmail.com and tbreton@eafit.edu.co

574-250-5322 (home) 574-261-9334 (office) 574-261-9294 (fax) 


\section{Introduction}

The international PISA testing program evaluates the reading, science, and mathematics literacy of 15 year-old students in over 60 countries. The test scores are calibrated to maintain a mean of 500 and a standard deviation of 100 for the 27 OECD countries that participated in PISA 2000 and had adequate response rates [OECD, 2014]. The U.S. consistently achieves scores that are about average for an OECD country, while East Asian countries consistently score much higher. As a consequence, public school officials and teachers in the U.S. are routinely criticized by politicians for U.S. students' failure to achieve higher scores [Simon, 2013].

The PISA questionnaires collect extensive information about each student that can be used to investigate what determines students' scores on these tests. The standard questionnaires do not collect information about ethnic characteristics, but the U.S. collects this information in an additional question when it implements the PISA test. This information can be used to investigate how average scores for U.S. students vary by major ethnic group in each subject. The ethnic groups available for self-declaration are White, Black, Hispanic, and Asian.

Table 1 shows the average scores of students for these ethnic groups in the PISA 2009 test of reading literacy. Black and Hispanic students scored considerably lower than White students, while Asian students scored higher on this test [Fleischman, Hopstock, Pelczar, and Shelley, 2011]. As will be shown later, similar differences are evident in the PISA 2012 results.

Table 1

Average Scores of U.S Students on PISA 2009 Reading Tests

\begin{tabular}{|c|c|c|c|c|}
\hline Overall & White & Black & Hispanic & Asian \\
\hline 500 & 525 & 441 & 466 & 541 \\
\hline
\end{tabular}

The White/Black difference in PISA 2009 reading scores of 84 points is quite substantial. The White/Hispanic difference is 59 points, which is lower but still substantial. Studies in European countries have found that students typically improve their scores by about 32 points in each additional year of schooling [Breton, 2015]. The implication is that 15-year-old Black U.S. students were about 2.5 years behind their White counterparts in their level of reading skills. Hispanic students were almost two years behind the White students. Similar patterns in students' average scores in reading literacy for Black and Hispanic students have been observed on other U.S. tests [Washington, 2001].

Speculation on the causes of the Black and Hispanic ethnic achievement gaps have included the low socioeconomic characteristics of the parents, disadvantages due to the use of less grammatically-correct language in these communities, parents' lower emphasis on teaching children reading skills, lower teacher expectations for Black and Hispanic students, and lower 
teacher qualifications and adverse peer effects in schools that have a higher share of Black and Hispanic students [Washington, 2001, Riegle-Crumb and Grodsky, 2010, and van Ewijk and Sleegers, 2010].

Recently researchers have begun to focus on the influence of ethnic group culture to explain school achievement. After controlling for numerous other differences, Jerrim [2015] concludes that the consistently higher achievement of Asian students in Australia has a cultural basis. Similarly, Breton and Canavire-Bacarrez [2017] find evidence that cultural characteristics explain a substantial portion of the consistently low student achievement on PISA tests in Latin America relative to Scandinavia.

In this paper I examine whether differences in average scores in mathematics and reading in PISA 2012 in four ethnic/racial groups in the U.S. can be explained by the families' socioeconomic characteristics or by the specific schools that students attend. I find that very little of the achievement gap can be explained by attendance at particular schools. The low socioeconomic characteristics of their families explains a large share of the negative ethnic gap for Hispanic students, but most of the negative gap for African-American students and the positive gap for Asian students is associated with their membership in these ethnic groups, which could be due to characteristics of these groups' cultures.

A substantial share of the gap in Black student achievement is due to the very low male scores, which stand out as being much lower than female scores in this ethnic group than in the others. The relationship between parental education and student's PISA scores varies across these ethnic groups, further indicating that (sub)cultural differences in ethnic groups have an effect on student achievement.

The remainder of this paper is structured as follows: Section II presents the methodology used in the study, section III presents the results, and section IV concludes.

\section{Methodology Used to Evaluate the PISA Results}

The PISA international tests have been developed to determine the level of students' skills across countries and to analyze what determines whether students successfully acquire these skills. Since students acquire their skills through activities at home, at school, outside of school, and as a function of their native abilities, it is difficult to ascertain why students have higher scores in some ethnic groups than in others.

Since policy-makers cannot change native abilities or students' family and cultural characteristics, most analyses of the causes of student test scores focus on the effect that school characteristics have on these scores. In these analyses students' personal and family characteristics are included as control variables, but they are not the focus of the analysis. 
In this analysis I focus on identifying the effect of family characteristics, schools, and the remaining ethnic gap for the Black, Hispanic, and Asian U.S. ethnic groups relative to White and other students on the PISA 2012 test scores in mathematics and reading. Since I am not interested in identifying why certain schools may obtain superior results, I control for differences in schools by including all of them as separate dummy variables.

Researchers typically assume that family and other characteristics affect student scores in the same way for all students within and across countries, so they estimate the average effect of each family characteristic on each student's score. In this analysis I initially follow this approach but also add a student's ethnic group as an additional explanatory variable. The coefficient on the ethnic group then quantifies the gap in the ethnic group's average score relative to the base group not explained by the other variables.

As additional socioeconomic and school characteristics are added to the model, the unexplained ethnic gap shrinks until the remaining gap is due specifically to membership in the ethnic group. This gap includes the effect of ethnic group culture on a student's test score.

Subsequently, I estimate the effect of socioeconomic and other characteristics on test scores separately by ethnic group to see how these characteristics affect student scores across groups. This is the same approach used in Breton and Canavire-Bacarreza [2017] to explain the much lower test scores in Latin America compared to Scandinavia. The results from the ethnicgroup-specific analysis provide more disaggregated information about how socioeconomic and other characteristics affect student scores differently in different ethnic groups.

In the model a student's test score (TS) is a function of gender (G), the student's family characteristics $\left(X_{i}\right)$, the student's ethnic group $\left(E_{j}\right)$ and a dummy variable for each school $\left(S_{k}\right)$ :

$$
T S_{j}=\alpha_{0}+G+\Sigma \alpha_{j} X_{i}+E_{j}+S_{k}+\varepsilon_{i}
$$

The characteristics I include in the model are limited by the information collected in the PISA questionnaires. The family characteristics are:

- the presence of the mother and the father in the home,

- the educational level of the parents,

- whether the student arrived in the U.S. after birth,

- whether the mother and father work full-time, and

- the number of books in the home

Each parent's level of schooling is included as two dummy variables, one for upper secondary, and one for university. No distinction is made for the type of university education completed. The effect of university schooling is additive to the effect of upper secondary schooling. The 
number of books in the home are included in PISA in six categories: $(0-10,11-25,26-100,101-$ $200,201-500,>500)$. I include these categories as dummy variables. I exclude 0-10 books as the base level.

There are no explicit income variables or proxies for income variables in the model. Unlike some of the other international test programs, the PISA data on family characteristics are collected from the students, not from the parents, so they do not include income data. My hope is that the parents' educational characteristics, presence in the home, and working status and the books at home control for family income.

Any effects of family income on test scores not explained by the included family characteristics end up as a residual effect attributed to membership in the ethnic group. The effect of other excluded characteristics affecting students in the ethnic group, such as any effect of discrimination on family income or any difference in teacher expectations for student achievement, are included in the effect of membership in the ethnic group. As a consequence, it is not possible to attribute the unexplained ethnic differences in test scores solely to the group's (sub)cultural characteristics.

Since PISA does not provide a complete test to every student, each student's score on the complete test is estimated using several techniques, which yields five plausible scores for each student for each test. For most students these scores are similar but not identical. In my analysis each student's score is the average of these five plausible scores. I separately analyze the determinants of the PISA score for mathematics and reading. I do not analyze the science scores.

The U.S. PISA 2012 data contain information for 4,978 students, including 2,553 white students, 641 black students, 1,176 Hispanic students, and 227 Asian students. These students attended 162 schools. I obtained these data from the NCAES web site. The Asian sample is small, so estimates of the effects of different characteristics in this group are not as statistically significant as in the other groups. The sample sizes of each group are related to the size of these groups in the U.S. population, but they are not directly proportional. PISA provides sample weights for each student's share of the U.S. population, which I use to create averages and to adjust the econometric analysis, so in theory the empirical results should be indicative of the effects of the various characteristics in the overall U.S. student population.

\section{Empirical Results}

Table 2 presents the results for the mathematics scores. The first five columns show the results for all the data, while the last four show the results for each ethnic group. Column 1 shows the effect of gender and ethnic group only. Column 2 shows the effects when family characteristics are added. Column 3 adds the effect of books at home. Column 4 adds the effect of schools. As the additional explanatory variables are added, the unexplained 
Table 2

Effect of Family and Cultural Characteristics and Schools on Mathematics Test Scores

\begin{tabular}{|c|c|c|c|c|c|c|c|c|c|}
\hline & 1 & 2 & 3 & 4 & 5 & 6 & 7 & 8 & 9 \\
\hline Sample & All & All & All & All & All & White & Black & Hisp & Asian \\
\hline Observations & 4978 & 4978 & 4978 & 4978 & 4978 & 2553 & 641 & 1176 & 227 \\
\hline Fixed Effects & No & No & No & Yes & Yes & No & No & No & No \\
\hline Female & $\begin{array}{l}-6.0 * \\
(2.3)\end{array}$ & $\begin{array}{l}-5.7^{*} \\
(2.2)\end{array}$ & $\begin{array}{l}-8.8^{*} \\
(2.1)\end{array}$ & $\begin{array}{c}-10.3^{*} \\
(2.0)\end{array}$ & $\begin{array}{l}-8.8^{*} \\
(2.1)\end{array}$ & $\begin{array}{c}-15.0^{*} \\
(2.9)\end{array}$ & $\begin{array}{c}9.8 \\
(5.6)\end{array}$ & $\begin{array}{c}-12.9^{*} \\
(4.3)\end{array}$ & $\begin{array}{c}-1.4 \\
(10.9)\end{array}$ \\
\hline Mom home & & $\begin{array}{l}28.7^{*} \\
(4.0)\end{array}$ & $\begin{array}{l}23.6 * \\
(3.8)\end{array}$ & $\begin{array}{l}22.5^{*} \\
(3.6)\end{array}$ & & $\begin{array}{c}26.5^{*} \\
(5.9)\end{array}$ & $\begin{array}{c}22.3^{*} \\
(9.0)\end{array}$ & $\begin{array}{c}17.5^{*} \\
(7.7)\end{array}$ & $\begin{array}{c}19.8 \\
(22.1)\end{array}$ \\
\hline Dad home & & $\begin{array}{l}10.1^{*} \\
(2.7)\end{array}$ & $\begin{array}{l}6.4^{*} \\
(2.6)\end{array}$ & $\begin{array}{c}5.5 \\
(2.5)\end{array}$ & & $\begin{array}{c}6.1 \\
(3.9)\end{array}$ & $\begin{array}{c}1.3 \\
(5.9)\end{array}$ & $\begin{array}{c}1.3 \\
(5.1)\end{array}$ & $\begin{array}{c}36.3 \\
(16.2)\end{array}$ \\
\hline Mom_sec & & $\begin{array}{l}17.2^{*} \\
(3.6)\end{array}$ & $\begin{array}{l}7.9 * \\
(3.5)\end{array}$ & $\begin{array}{c}5.4 \\
(3.4)\end{array}$ & & $\begin{array}{c}6.1 \\
(6.5)\end{array}$ & $\begin{array}{c}3.8 \\
(9.8) \\
\end{array}$ & $\begin{array}{c}9.1 \\
(5.3)\end{array}$ & $\begin{array}{c}15.0 \\
(17.3)\end{array}$ \\
\hline Mom_univ & & $\begin{array}{c}16.4^{*} \\
(2.7)\end{array}$ & $\begin{array}{l}9.8^{*} \\
(2.6)\end{array}$ & $\begin{array}{c}6.2 \\
(2.5) \\
\end{array}$ & & $\begin{array}{l}12.7^{*} \\
(3.3)\end{array}$ & $\begin{array}{l}-0.8 \\
(6.5)\end{array}$ & $\begin{array}{l}14.7 \\
(6.7)\end{array}$ & $\begin{array}{c}11.0 \\
(15.9)\end{array}$ \\
\hline Dad_sec & & $\begin{array}{l}16.5^{*} \\
(3.2)\end{array}$ & $\begin{array}{l}14.0 * \\
(3.1)\end{array}$ & $\begin{array}{l}8.1^{*} \\
(3.0)\end{array}$ & & $\begin{array}{l}22.3^{*} \\
(5.1)\end{array}$ & $\begin{array}{l}26.5^{*} \\
(7.8)\end{array}$ & $\begin{array}{c}5.0 \\
(5.2)\end{array}$ & $\begin{array}{c}-2.1 \\
(17.3)\end{array}$ \\
\hline Dad_univ & & $\begin{array}{l}26.9 * \\
(2.8)\end{array}$ & $\begin{array}{l}19.7^{*} \\
(2.7)\end{array}$ & $\begin{array}{l}14.2^{*} \\
(2.7)\end{array}$ & & $\begin{array}{l}22.9 * \\
(3.5)\end{array}$ & $\begin{array}{l}14.6 \\
(7.2)\end{array}$ & $\begin{array}{c}5.4 \\
(7.2)\end{array}$ & $\begin{array}{c}24.4 \\
(17.0)\end{array}$ \\
\hline $\begin{array}{l}\text { Mom work } \\
\text { full time }\end{array}$ & & $\begin{array}{c}2.3 \\
(2.2) \\
\end{array}$ & $\begin{array}{c}4.1 \\
(2.2)\end{array}$ & $\begin{array}{c}1.5 \\
(2.1)\end{array}$ & & $\begin{array}{c}3.9 \\
(3.0)\end{array}$ & $\begin{array}{c}7.7 \\
(5.9)\end{array}$ & $\begin{array}{l}-0.3 \\
(4.4)\end{array}$ & $\begin{array}{c}29.0 \\
(11.4)\end{array}$ \\
\hline $\begin{array}{l}\text { Dad work } \\
\text { full time }\end{array}$ & & $\begin{array}{c}6.0 \\
(2.7)\end{array}$ & $\begin{array}{c}5.4 \\
(2.6)\end{array}$ & $\begin{array}{c}5.5 \\
(2.5)\end{array}$ & & $\begin{array}{l}-0.2 \\
(3.9)\end{array}$ & $\begin{array}{c}7.5 \\
(6.3)\end{array}$ & $\begin{array}{l}13.6^{*} \\
(5.1)\end{array}$ & $\begin{array}{c}4.9 \\
(12.7)\end{array}$ \\
\hline Immigrant & & $\begin{array}{c}-11.3^{*} \\
(4.2)\end{array}$ & $\begin{array}{l}-7.9 \\
(4.1)\end{array}$ & $\begin{array}{l}-9.1 \\
(4.0)\end{array}$ & & $\begin{array}{c}2.6 \\
(10.6)\end{array}$ & $\begin{array}{c}21.4 \\
(12.5)\end{array}$ & $\begin{array}{l}-9.2 \\
(5.6)\end{array}$ & $\begin{array}{c}-30.5 \\
(12.2)\end{array}$ \\
\hline $11-25$ bks & & & $\begin{array}{c}19.5^{*} \\
(3.3)\end{array}$ & $\begin{array}{c}13.7^{*} \\
(3.2)\end{array}$ & & $\begin{array}{c}3.1 \\
(5.4)\end{array}$ & $\begin{array}{c}32.2^{*} \\
(7.6) \\
\end{array}$ & $\begin{array}{c}27.1^{*} \\
(5.5)\end{array}$ & $\begin{array}{c}32.4 \\
(21.1)\end{array}$ \\
\hline $26-100$ bks & & & $\begin{array}{l}37.3^{*} \\
(3.0)\end{array}$ & $\begin{array}{l}28.1^{*} \\
(2.9)\end{array}$ & & $\begin{array}{c}23.6^{*} \\
(4.7)\end{array}$ & $\begin{array}{l}44.6^{*} \\
(7.4)\end{array}$ & $\begin{array}{l}51.7^{*} \\
(5.7)\end{array}$ & $\begin{array}{l}\text { 44.9* } \\
(16.5)\end{array}$ \\
\hline $101-200$ bks & & & $\begin{array}{l}52.3^{*} \\
(3.7)\end{array}$ & $\begin{array}{l}38.3^{*} \\
(3.6)\end{array}$ & & $\begin{array}{l}42.6^{*} \\
(5.4)\end{array}$ & $\begin{array}{c}45.9^{*} \\
(9.7)\end{array}$ & $\begin{array}{c}48.0^{*} \\
(8.3)\end{array}$ & $\begin{array}{l}60.1^{*} \\
(19.4)\end{array}$ \\
\hline 201-500 bks & & & $\begin{array}{l}76.7^{*} \\
(4.1)\end{array}$ & $\begin{array}{l}63.7^{*} \\
(4.0)\end{array}$ & & $\begin{array}{l}66.5^{*} \\
(5.6)\end{array}$ & $\begin{array}{l}64.8^{*} \\
(12.5)\end{array}$ & $\begin{array}{l}90.1^{*} \\
(10.4)\end{array}$ & $\begin{array}{l}78.7^{*} \\
(22.0)\end{array}$ \\
\hline$>500 \mathrm{bks}$ & & & $\begin{array}{c}57.6^{*} \\
(5.7)\end{array}$ & $\begin{array}{c}48.4^{*} \\
(5.5)\end{array}$ & & $\begin{array}{c}44.4^{*} \\
(7.1)\end{array}$ & $\begin{array}{c}50.7 \\
(21.6)\end{array}$ & $\begin{array}{l}75.9 * \\
(18.4)\end{array}$ & $\begin{array}{c}20.8 \\
(34.8) \\
\end{array}$ \\
\hline Black & $\begin{array}{c}-79.3^{*} \\
(3.6)\end{array}$ & $\begin{array}{c}-70.4^{*} \\
(3.5)\end{array}$ & $\begin{array}{c}-60.2^{*} \\
(3.4)\end{array}$ & $\begin{array}{c}-47.1^{*} \\
(3.8)\end{array}$ & $\begin{array}{c}-55.1^{*} \\
(4.0)\end{array}$ & & & & \\
\hline Hispanic & $\begin{array}{c}-44.8^{*} \\
(2.8) \\
\end{array}$ & $\begin{array}{c}-21.8^{*} \\
(2.9) \\
\end{array}$ & $\begin{array}{c}-13.8^{*} \\
(2.8)\end{array}$ & $\begin{array}{c}-11.7^{*} \\
(3.2)\end{array}$ & $\begin{array}{c}-27.5^{*} \\
(3.3) \\
\end{array}$ & & & & \\
\hline Asian & $\begin{array}{c}49.5^{*} \\
(5.5)\end{array}$ & $\begin{array}{c}52.7^{*} \\
(5.3)\end{array}$ & $\begin{array}{l}51.7^{*} \\
(5.1)\end{array}$ & $\begin{array}{c}42.9 * \\
(5.3)\end{array}$ & $\begin{array}{c}37.9 * \\
(5.6)\end{array}$ & & & & \\
\hline Constant & $\begin{array}{c}502.8^{*} \\
(1.9)\end{array}$ & $\begin{array}{c}416.8^{*} \\
(4.9)\end{array}$ & $\begin{array}{c}403.0^{*} \\
(4.8)\end{array}$ & $\begin{array}{l}390.0^{*} \\
(12.9)\end{array}$ & $\begin{array}{l}442.9^{*} \\
(13.3)\end{array}$ & $\begin{array}{c}413.6^{*} \\
(8.4)\end{array}$ & $\begin{array}{l}329.4 * \\
(12.0)\end{array}$ & $\begin{array}{c}396.7^{*} \\
(8.9)\end{array}$ & $\begin{array}{c}422.7^{*} \\
(27.4)\end{array}$ \\
\hline $\mathrm{R}^{2}$ & 0.14 & 0.24 & 0.30 & 0.40 & 0.33 & 0.19 & 0.17 & 0.18 & 0.26 \\
\hline
\end{tabular}


differences in test scores due to membership in the ethnic group become smaller. Column 5 shows the effect on scores of gender and schools alone.

The effect of Black, Hispanic, and Asian ethnic group membership in the first five columns is measured relative to the students in the White, multi-cultural, and other groups. As shown in column 1, initially the Black group exhibits an unexplained achievement gap in mathematics of 79 points, which declines to 70 and then 60 points as family characteristics and books at home are added to the model. It declines to 47 points when the schools are added. Implicitly $59 \%$ of the Black achievement gap cannot be explained by either family or school characteristics.

It is not possible to determine accurately the contribution of the schools to the Black achievement gap. All of the characteristics in the model are correlated, so the estimated effect of each characteristic depends on the other variables included in the model. It is possible to bound the effect of the schools by looking at the changes in the unexplained ethnic group effect when schools are added either first or last to the model. Column 5 shows that when the schools are added first, the unexplained Black gap shrinks by 24 points. Columns 3 and 4 show that when schools are added last, they reduce the unexplained gap by 13 points. These estimates indicate that the particular schools attended by Black students explain 13-24 points of the 79-point ethnic achievement gap, or about $22 \%$ of the gap.

The total effect of attendance at a particular school explains relatively little of the Black achievement gap, and this effect includes any adverse peer effects from attending a school with a large share of Black students. So the adverse effect of "bad" teachers on Black student achievement is implicitly very small.

The effect of the low socioeconomic characteristics of Black families is also relatively small. This effect is somewhere between 10 and 20 points, since the effects of books in the home may include cultural effects. The clear effect of low socioeconomic characteristics is only 10 points, or $13 \%$ of the Black achievement gap. In trying to address the achievement gap in the black community, the conclusion must be that changing the conditions in the community, including parental behavior affecting student learning, is more important than changing educational practices in the schools.

Table 3 summarizes these effects for the Black ethnic group and includes the same calculations for the Hispanic and Asian ethnic groups. The results show that the importance of the different characteristics is quite different in these other groups. Family characteristics explain a much larger share of the Hispanic achievement gap, with cultural characteristics explaining only 12 points. There is also less clarity about the size of the family effect, since it is less clearly distinct from the effect of the schools in the econometric analysis. The implication 
of the Hispanic analysis is that the ethnic achievement gap in this group may be in large part a transitional problem that will diminish as Hispanic parents become more educated.

The distribution of effects for the Asian achievement gap is also quite different. In this group the cultural effect explains most of the positive gap. Family characteristics have a small negative effect, but they are overcome by the positive effect of the schools and of the Asian culture. Most of the positive achievement gap for the Asian students appears to be due to the ethnic group's cultural characteristics. These results are consistent with Jerrim's findings for Australia.

\begin{tabular}{|l|c|c|c|c|c|}
\hline \multicolumn{7}{|c|}{ Causes of Ethnic Gaps in PISA 2012 Mathematics Scores } \\
\hline $\begin{array}{l}\text { Ethnic } \\
\text { Group }\end{array}$ & Ethnic Gap & $\begin{array}{c}\text { Family } \\
\text { Characteristics }\end{array}$ & Schools & $\begin{array}{c}\text { Culture \& } \\
\text { Unexplained }\end{array}$ & $\begin{array}{c}\text { Culture } \\
\text { Share }\end{array}$ \\
\hline Blacks & -79 points & $-(8-19)$ points & $-(13-24)$ points & -47 points & $59 \%$ \\
\hline Hispanics & -45 points & $-(16-31)$ points & $-(2-17)$ points & -12 points & $27 \%$ \\
\hline Asians & +49.5 points & $-(2-5.5)$ points & $+(9-12)$ points & +43 points & $87 \%$ \\
\hline
\end{tabular}

If ethnic culture affects student test scores, cultural differences are likely to be apparent in differing effects of family characteristics on student scores in each group. Columns 6 to 9 show the estimates of the model for each of the four ethnic groups.

There are substantial differences across groups in the effect of some of the factors on student's scores. The first difference is in the effect of gender on mathematics scores. Females in the White and Hispanic groups score lower than males in mathematics, while they have similar scores in the Asian group and higher scores in the Black ethnic group. Since Black scores are quite low overall, the implication is that while Black females have relatively low scores, Black males have even lower relative scores compared to other ethnic groups.

The next major difference is related to the effect of the mother's education on test scores. In most groups students whose mother has a university education do better in mathematics. This is not true in the Black ethnic group, where this credential appears to have no effect. This result is surprising and could be due to misreporting of family characteristics by the Black students, or it could indicate that Black mothers relate differently to their children than other mothers relative to their schoolwork. 
The next major difference is related to the effect of the father's education on test scores, which typically has a large positive effect. This is not true in the Hispanic ethnic group where the father's education has little effect on student scores.

The parents' status of working full-time does not have much effect, except in the Hispanic group and Asian groups. In the Hispanic group when the father has full-time work, student scores are higher. In the Asian group when the mother has full-time work, student scores are higher.

Another interesting difference is the effect of the student having immigrated to the U.S. For Hispanics and Asians, all other things being equal, this effect is negative, while for Blacks the effect is substantially positive (21 points). This result is consistent with an interpretation of the data to indicate that the Black (sub)culture in the U.S. is not particularly supportive of academic achievement, so immigrant Black students have substantially greater school achievement than domestic Black students.

Table 4 presents the same models shown in Table 2 for U.S. scores on the PISA reading test. These results differ strongly with respect to the effect of gender. Females perform substantially better in reading than males across all ethnic groups, which the opposite of the situation with respect to mathematics. In the case of Black students, this results in Black females averaging 50 points higher in reading than Black males. The patterns for the effects of the other characteristics on reading scores across ethnic groups are quite similar to their effects on mathematics' scores. The absolute unexplained effect (in points) of membership in the Black and Hispanic ethnic groups is slightly smaller in reading than in mathematics, while the positive unexplained effect of membership in the Asian group is considerably smaller in reading than in mathematics ( +20 points vs. +43 points).

Table 5 shows the effect of each major factor on the ethnic achievement gap in reading. Overall the negative gap attributed to culture is slightly smaller for Blacks and Hispanics than in mathematics, and the positive gap in reading is only half as large as in mathematics for Asian students. Again, there is no indication that schools are a major contributor to the negative reading gap for Blacks and Hispanics, and in the case of Asian students, the schools appear to be a major positive contributor to student scores (20 points).

The similarity in the findings for the causes of ethnic achievement gaps in mathematics and reading skills provides assurance that the findings are valid. It appears that that the ethnic group subculture gives Asian students an advantage and Black students a disadvantage in school achievement. In the case of Black students, the effect of culture and any adverse conditions in the community is more important than any negative effect due to poor schools. 


\section{Table 4}

Effect of Family and Cultural Characteristics and Schools on Reading Test Scores

\begin{tabular}{|c|c|c|c|c|c|c|c|c|c|}
\hline & 1 & 2 & 3 & 4 & 5 & 6 & 7 & 8 & 9 \\
\hline Sample & All & All & All & All & All & White & Black & Hisp & Asian \\
\hline Observations & 4978 & 4978 & 4978 & 4978 & 4978 & 2553 & 641 & 1176 & 227 \\
\hline Fixed Effects & No & No & No & Yes & Yes & No & No & No & No \\
\hline Female & $\begin{array}{l}29.6^{*} \\
(2.4)\end{array}$ & $\begin{array}{l}30.1^{*} \\
(2.2)\end{array}$ & $\begin{array}{l}26.7^{*} \\
(2.1)\end{array}$ & $\begin{array}{l}24.6^{*} \\
(2.0)\end{array}$ & $\begin{array}{l}26.1^{*} \\
(2.1)\end{array}$ & $\begin{array}{c}20.0^{*} \\
(2.9)\end{array}$ & $\begin{array}{l}49.7 \\
(6.2)\end{array}$ & $\begin{array}{l}20.3^{*} \\
(4.3)\end{array}$ & $\begin{array}{c}34.2 \\
(10.5)\end{array}$ \\
\hline Mom home & & $\begin{array}{l}22.5^{*} \\
(4.1)\end{array}$ & $\begin{array}{l}16.7^{*} \\
(3.9)\end{array}$ & $\begin{array}{l}15.9 * \\
(3.7)\end{array}$ & & $\begin{array}{l}13.6^{*} \\
(6.0)\end{array}$ & $\begin{array}{c}9.6 \\
(10.5)\end{array}$ & $\begin{array}{l}10.9 \\
(7.7)\end{array}$ & $\begin{array}{c}3.7 \\
(21.3)\end{array}$ \\
\hline Dad home & & $\begin{array}{l}14.1^{*} \\
(2.8)\end{array}$ & $\begin{array}{l}10.3^{*} \\
(2.7)\end{array}$ & $\begin{array}{l}10.2^{*} \\
(2.5)\end{array}$ & & $\begin{array}{c}8.0 \\
(4.0)\end{array}$ & $\begin{array}{c}8.2 \\
(6.5)\end{array}$ & $\begin{array}{c}4.3 \\
(5.2)\end{array}$ & $\begin{array}{c}36.4 \\
(15.6)\end{array}$ \\
\hline Mom_sec & & $\begin{array}{l}15.8^{*} \\
(3.7)\end{array}$ & $\begin{array}{c}6.0 \\
(3.6)\end{array}$ & $\begin{array}{c}4.9 \\
(3.4)\end{array}$ & & $\begin{array}{c}3.1 \\
(6.6)\end{array}$ & $\begin{array}{c}15.3 \\
(10.9)\end{array}$ & $\begin{array}{c}2.5 \\
(5.3)\end{array}$ & $\begin{array}{c}11.7 \\
(16.7)\end{array}$ \\
\hline Mom_univ & & $\begin{array}{l}16.9 * \\
(2.8) \\
\end{array}$ & $\begin{array}{c}10.1^{*} \\
(2.7)\end{array}$ & $\begin{array}{c}5.1 \\
(2.5)\end{array}$ & & $\begin{array}{l}13.4^{*} \\
(3.4)\end{array}$ & $\begin{array}{c}0.2 \\
(7.2)\end{array}$ & $\begin{array}{l}11.1 \\
(6.8)\end{array}$ & $\begin{array}{c}23.2 \\
(15.4)\end{array}$ \\
\hline Dad_sec & & $\begin{array}{l}23.7^{*} \\
(3.3)\end{array}$ & $\begin{array}{l}21.1^{*} \\
(3.2)\end{array}$ & $\begin{array}{l}13.1^{*} \\
(3.0)\end{array}$ & & $\begin{array}{l}29.4^{*} \\
(5.2)\end{array}$ & $\begin{array}{l}31.0^{*} \\
(8.6)\end{array}$ & $\begin{array}{l}13.3 \\
(5.2)\end{array}$ & $\begin{array}{c}8.7 \\
(16.7)\end{array}$ \\
\hline Dad_univ & & $\begin{array}{l}21.4^{*} \\
(3.9)\end{array}$ & $\begin{array}{l}14.8^{*} \\
(2.8)\end{array}$ & $\begin{array}{l}9.5^{*} \\
(2.7)\end{array}$ & & $\begin{array}{l}19.5^{*} \\
(3.6)\end{array}$ & $\begin{array}{l}14.3 \\
(8.0)\end{array}$ & $\begin{array}{l}-3.7 \\
(7.3)\end{array}$ & $\begin{array}{c}8.8 \\
(16.4)\end{array}$ \\
\hline $\begin{array}{l}\text { Mom work } \\
\text { full time }\end{array}$ & & $\begin{array}{c}3.3 \\
(2.3) \\
\end{array}$ & $\begin{array}{c}4.9 \\
(2.2)\end{array}$ & $\begin{array}{c}3.3 \\
(2.1)\end{array}$ & & $\begin{array}{c}2.4 \\
(3.1)\end{array}$ & $\begin{array}{l}11.0 \\
(6.5)\end{array}$ & $\begin{array}{c}0.6 \\
(4.4)\end{array}$ & $\begin{array}{c}29.0 \\
(11.0)\end{array}$ \\
\hline $\begin{array}{l}\text { Dad work } \\
\text { full time }\end{array}$ & & $\begin{array}{l}7.4^{*} \\
(2.8) \\
\end{array}$ & $\begin{array}{c}6.6 \\
(2.7) \\
\end{array}$ & $\begin{array}{c}5.0 \\
(2.5)\end{array}$ & & $\begin{array}{c}0.7 \\
(4.0)\end{array}$ & $\begin{array}{c}3.3 \\
(6.9)\end{array}$ & $\begin{array}{c}14.8^{*} \\
(5.1)\end{array}$ & $\begin{array}{c}5.4 \\
(12.2)\end{array}$ \\
\hline Immigrant & & $\begin{array}{c}-12.4^{*} \\
(4.4)\end{array}$ & $\begin{array}{l}-8.9 \\
(4.2)\end{array}$ & $\begin{array}{l}-11.8 \\
(4.1)\end{array}$ & & $\begin{array}{c}7.0 \\
(10.8)\end{array}$ & $\begin{array}{c}16.9 \\
(13.8)\end{array}$ & $\begin{array}{l}-12.0 \\
(5.7)\end{array}$ & $\begin{array}{l}-33.9 * \\
(11.8)\end{array}$ \\
\hline $11-25$ bks & & & $\begin{array}{c}23.7^{*} \\
(3.4)\end{array}$ & $\begin{array}{c}16.9 * \\
(3.2)\end{array}$ & & $\begin{array}{c}5.4 \\
(5.5)\end{array}$ & $\begin{array}{c}44.9 * \\
(8.4) \\
\end{array}$ & $\begin{array}{c}26.5^{*} \\
(5.6)\end{array}$ & $\begin{array}{c}33.3 \\
(20.4)\end{array}$ \\
\hline $26-100$ bks & & & $\begin{array}{c}40.7^{*} \\
(3.1)\end{array}$ & $\begin{array}{l}30.1^{*} \\
(3.0)\end{array}$ & & $\begin{array}{l}24.6^{*} \\
(4.8)\end{array}$ & $\begin{array}{c}56.2^{*} \\
(8.2)\end{array}$ & $\begin{array}{l}53.1^{*} \\
(5.8)\end{array}$ & $\begin{array}{l}41.5^{*} \\
(15.9)\end{array}$ \\
\hline $101-200$ bks & & & $\begin{array}{l}61.2 * \\
(3.8)\end{array}$ & $\begin{array}{l}45.4^{*} \\
(3.7)\end{array}$ & & $\begin{array}{l}49.1^{*} \\
(5.5)\end{array}$ & $\begin{array}{l}64.5^{*} \\
(10.8)\end{array}$ & $\begin{array}{c}53.7^{*} \\
(8.4)\end{array}$ & $\begin{array}{l}\text { 63.0* } \\
(18.7)\end{array}$ \\
\hline 201-500 bks & & & $\begin{array}{l}75.2^{*} \\
(4.2)\end{array}$ & $\begin{array}{l}60.4^{*} \\
(4.0)\end{array}$ & & $\begin{array}{l}62.4^{*} \\
(5.7)\end{array}$ & $\begin{array}{l}63.5^{*} \\
(13.9)\end{array}$ & $\begin{array}{l}94.4^{*} \\
(10.5)\end{array}$ & $\begin{array}{l}\text { 71.1* } \\
(21.2)\end{array}$ \\
\hline$>500 \mathrm{bks}$ & & & $\begin{array}{l}52.6^{*} \\
(5.8)\end{array}$ & $\begin{array}{c}41.7^{*} \\
(5.5)\end{array}$ & & $\begin{array}{c}35.9^{*} \\
(7.3)\end{array}$ & $\begin{array}{c}57.7 \\
(24.0)\end{array}$ & $\begin{array}{l}56.0^{*} \\
(18.6)\end{array}$ & $\begin{array}{c}26.0 \\
(33.6) \\
\end{array}$ \\
\hline Black & $\begin{array}{c}-69.3^{*} \\
(3.7)\end{array}$ & $\begin{array}{c}-59.0^{*} \\
(3.6)\end{array}$ & $\begin{array}{c}-48.7^{*} \\
(3.5)\end{array}$ & $\begin{array}{c}-43.9 * \\
(3.9)\end{array}$ & $\begin{array}{c}-52.1^{*} \\
(4.0)\end{array}$ & & & & \\
\hline Hispanic & $\begin{array}{c}-35.8^{*} \\
(2.8) \\
\end{array}$ & $\begin{array}{c}-11.4^{*} \\
(3.0)\end{array}$ & $\begin{array}{l}-3.5^{*} \\
(2.9) \\
\end{array}$ & $\begin{array}{l}-7.2^{*} \\
(3.3) \\
\end{array}$ & $\begin{array}{c}-23.5^{*} \\
(3.3) \\
\end{array}$ & & & & \\
\hline Asian & $\begin{array}{c}37.0^{*} \\
(5.6)\end{array}$ & $\begin{array}{l}41.7^{*} \\
(5.4)\end{array}$ & $\begin{array}{c}40.1^{*} \\
(5.2)\end{array}$ & $\begin{array}{l}20.0 * \\
(5.4)\end{array}$ & $\begin{array}{l}14.3^{*} \\
(5.6)\end{array}$ & & & & \\
\hline Constant & $\begin{array}{c}598.7^{*} \\
(1.9)\end{array}$ & $\begin{array}{c}410.1^{*} \\
(5.0)\end{array}$ & $\begin{array}{c}395.3^{*} \\
(5.0)\end{array}$ & $\begin{array}{l}382.1^{*} \\
(13.1)\end{array}$ & $\begin{array}{l}435.5^{*} \\
(13.4)\end{array}$ & $\begin{array}{c}417.3^{*} \\
(8.6)\end{array}$ & $\begin{array}{l}319.9 * \\
(13.3)\end{array}$ & $\begin{array}{c}406.3^{*} \\
(9.0)\end{array}$ & $\begin{array}{l}419.5^{*} \\
(26.4)\end{array}$ \\
\hline $\mathrm{R}^{2}$ & 0.12 & 0.22 & 0.29 & 0.41 & 0.34 & 0.19 & 0.28 & 0.19 & 0.30 \\
\hline
\end{tabular}




\begin{tabular}{|l|c|c|c|c|c|}
\hline \multicolumn{7}{|c|}{ Causes of Ethnic Gaps in PISA 2012 Reading Scores } \\
\hline $\begin{array}{l}\text { Ethnic } \\
\text { Group }\end{array}$ & Ethnic Gap & $\begin{array}{c}\text { Family } \\
\text { Characteristics }\end{array}$ & Schools & $\begin{array}{c}\text { Culture \& } \\
\text { Unexplained }\end{array}$ & $\begin{array}{c}\text { Culture } \\
\text { Share }\end{array}$ \\
\hline Blacks & -69 points & $-(8-19)$ points & $-(5-17)$ points & -44 points & $59 \%$ \\
\hline Hispanics & -36 points & $-(17-33)$ points & -12 to +4 points & -7 points & $27 \%$ \\
\hline Asians & +37 points & $-(3-6)$ points & $+(20-23)$ points & +20 points & $87 \%$ \\
\hline
\end{tabular}

The models do not account for how the share of students from each ethnic group in class affects the unexplained achievement gap for (all) students in each school. Figure 1 shows the school effect in the 162 schools in the data set as a function of the share of Black students in the class. The results show that schools are more likely to make a negative contribution to students' scores as the share of Black students in the class increases. A student's expected score declines once a class has more than $10 \%$ black students, and there are no schools with a positive effect on student scores that have a Black student share above $45 \%$. The mean effect of a high share of black students (over $80 \%$ ) on school performance is -40 points.

Figure 1

School Effect on Mathematics Score vs. Share of Black Students in the Class

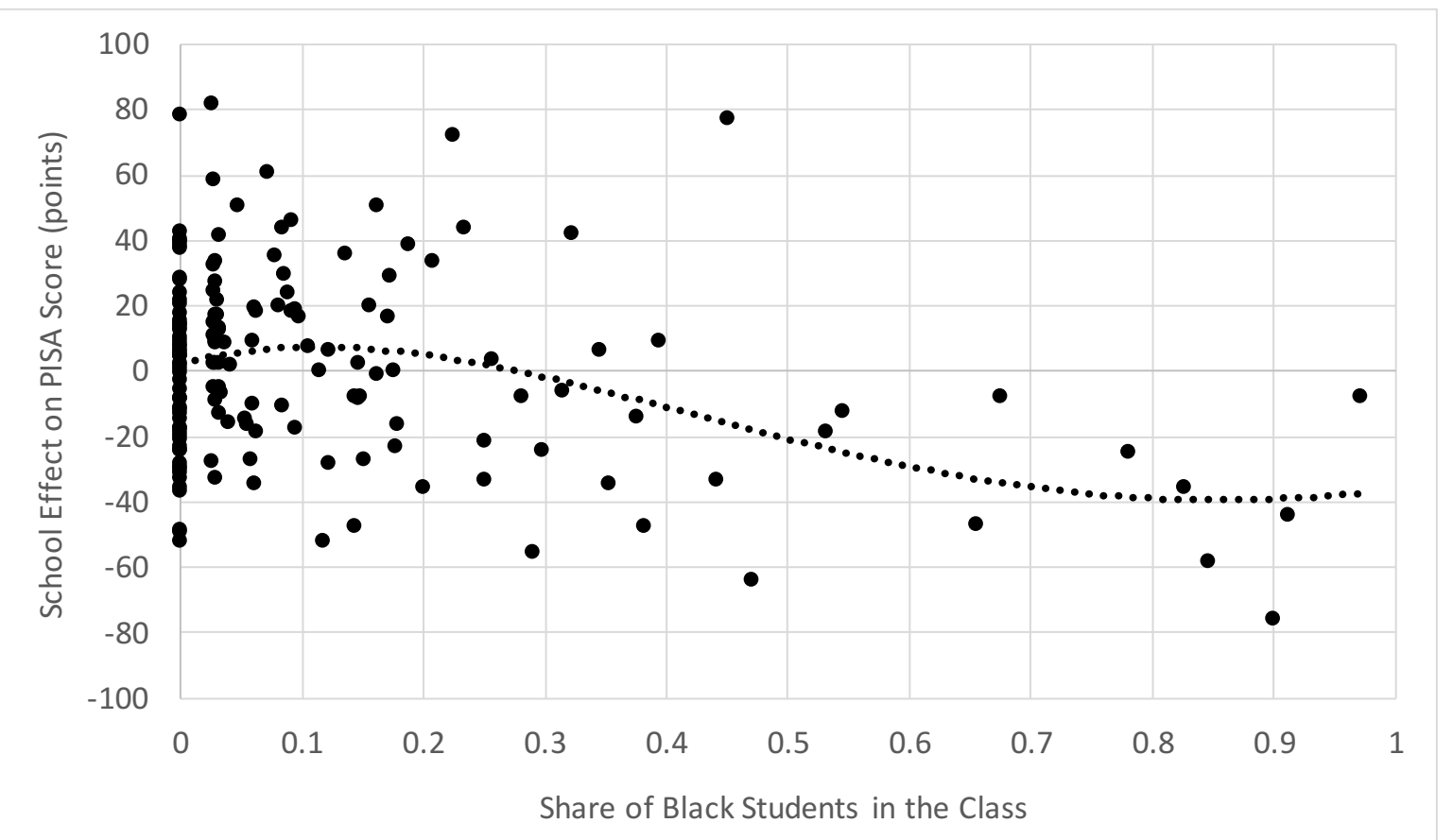


There are several possible explanations for this situation, which means that a student's score in these schools is worse than would be expected given his/her gender and family characteristics. Schools with a high share of Black students are likely to be in communities with a high black share in the population. Although I control for certain family characteristics, it may be that other adverse family characteristics not included in the study are more likely in predominately black communities and are adversely affecting student achievement in their schools (e.g., drug trafficking). It is also possible that these areas have community characteristics (e.g., a high incidence of violence) that are adversely affecting student achievement in the school. Alternatively, it may be that a relative lack of support in the black community for student achievement has a negative effect on the school environment that increases as the share of Black students in the class rises. This situation could be exhibited through an adverse peer effect.

Figure 2 shows the same analysis of the effect of a rising share of Hispanics in a class on the school effect on student achievement. A rising share of Hispanic students has a negative effect on school performance once the share of Hispanics exceeds $15 \%$. In this ethnic group, however, the adverse effect of a large share of Hispanics in class is small, only about -8 points for classes that are over $80 \%$ Hispanic.

Figure 2

School Effect on Mathematics Score vs. Share of Hispanic Students in the Class

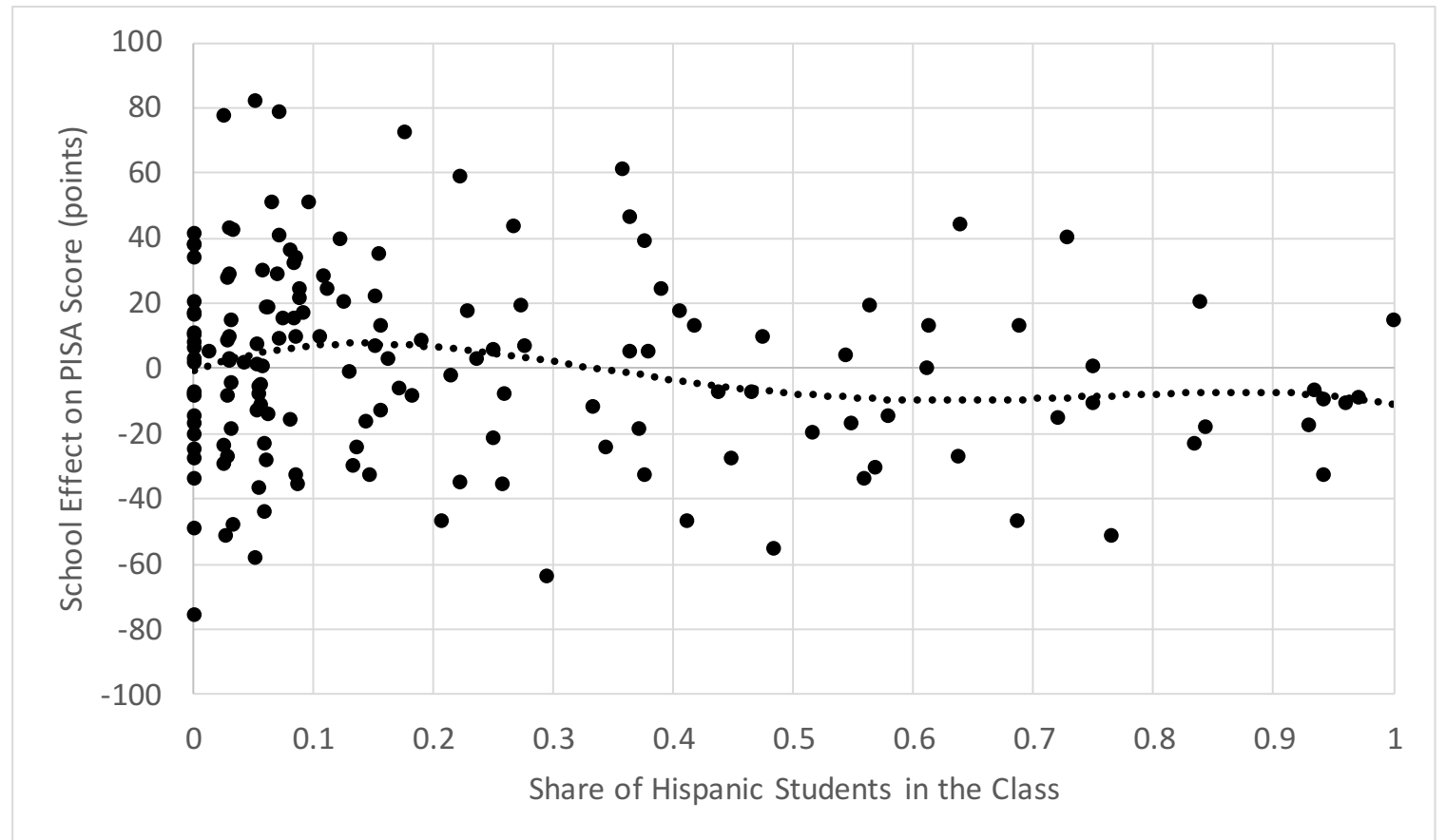


Table 6 provides data about the share of students' parents (according to them) who have completed college by ethnic group to further identify important differences. The Asian group stands out in that parents on average are more educated than parents in the White group. The Hispanic group stands out because it is so much less educated than any other ethnic group. The Black group stands out because the females are much more educated than the males. The much lower average test scores of males relative to females in the Black ethnic group is consistent with males' lower rate of completion of a college education.

\begin{tabular}{|l|c|c|c|c|}
\hline \multicolumn{5}{|c|}{ Table 6 } \\
& Reported Share of Parents with College Education by Ethnic Group \\
\hline & White & Black & Hispanic & Asian \\
\hline Mother & .42 & .37 & .16 & .45 \\
\hline Father & .38 & .27 & .13 & .50 \\
\hline
\end{tabular}

Table 7 shows the number of books at home for students whose mother has a college education and also shows the share of fathers at home for these mothers, as reported by the students. White and Asian homes with college-educated mothers have similar numbers of books, but Black and Hispanic homes have only half as many. There are several possible interpretations of this difference. One possibility is that Black and Hispanic culture is less oriented toward book-reading that White and Asian culture. For Hispanics this explanation is consistent with Breton and Canavire-Bacarreza's [2017] findings that families in seven Latin American countries have unusually low levels of books at home compared to other countries with similar levels of education and GDP/capita.

Table 7

Books at Home and Fathers at Home in Families with a College-educated Mother

\begin{tabular}{|l|c|c|c|c|}
\hline & White & Black & Hispanic & Asian \\
\hline Number of Books at home & 190 & 95 & 100 & 173 \\
\hline Father at home (share) & .86 & .56 & .71 & .89 \\
\hline
\end{tabular}

Table 7 also shows that Black and Hispanic students whose mothers have a college education are much less likely to have a father living at home than White and Asian students. As a consequence, Black and Hispanic families are likely to have less income, so the lower number of books at home could be a measure of the family's lower level of income. These two sets of data reinforce the observations earlier that low Black and Hispanic test scores are due in part to the poorer socioeconomic conditions of their families. 


\section{Conclusions}

Extensive testing of U.S. students consistently reveals that Black and Hispanic students as groups score lower than White students on achievement tests, while Asian students score higher. In this study I replicate these findings for 15-year-old students taking the PISA 2012 tests of mathematics and reading literacy. I then investigate whether family characteristics, schools, or a residual ethnic gap explain these differences in student achievement.

I find that family characteristics and schools cannot explain the high negative achievement gap for Black students and the high positive gap for Asian students. In contrast, these differences do explain most of the negative gap for Hispanic students. I also find that a high share of Black students in a school generally is associated with an additional negative effect on student achievement beyond that explained by their family characteristics. Schools with a Black share of students over $80 \%$ in class on average have a negative effect of -40 points (for all students) on students' mathematics scores. A negative effect is also observed in schools with a high share of Hispanic students, but it is much smaller (-8 points).

It is difficult to determine from the data why there is such a large unexplained negative student achievement gap for Black students relative to other ethnic groups. But various elements of the results in this study provide evidence that the culture in the black community is not as supportive of school achievement as the culture in the white community, while the opposite is true in the Asian community. 


\section{References}

Breton, Theodore R., 2015, "Higher Test Scores or More Schooling? Another Look at the Causes of Economic Growth," Journal of Human Capital, v9, n2, 239-263

Breton, Theodore R. and Canavire-Bacarreza, Gustavo, 2017, "Low Test Scores in Latin America: Poor Schools, Poor Families, or Something Else?" Compare: A Journal of Comparative and International Education, forthcoming

Fleischman, Howard L., Hopstock, Paul J., Pelsczar, Marisa P., and Shelley, Brooke E., 2010, Highlights from PISA 2009: Performance of U.S. 15-Year-Old Students in Reading, Mathematics, and Science Literacy in an International Context, U.S. Department of Education, NCES 2011-004

Fuchs, Thomas, and Woessmann, Ludger, 2007, "What accounts for international differences in student performance? A re-examination using PISA data," Empirical Economics, 32, 433-464

Jerrim, John, 2015, "Why do East Asian children perform so well in PISA? An investigation of Western-born children of East Asian descent," Oxford Review of Education, v41, n3, 310-333

OECD, 2014, “PISA 2012 Technical Report, https://www.oecd.org/pisa/pisaproducts/PISA2012-technical-report-final.pdf

Riegle-Crumb, Catherine, and Grodsky, Eric, 2010, "Racial-ethnic Differences at the Intersection of Math Course-taking and Achievement," Sociology of Education, v83, n3, 248-270

Simon, Stephanie, 2013, "PISA Results: 'Educational Stagnation,'” Politico Magazine, 12/03/2013

Van Ewijk, Reyn, and Sleegers, Peter, 2010, "Peer ethnicity and achievement: a meta-analysis into the compositional effect," School Effectiveness and School Improvement, v21, n3, 237-265

Washington, Julie A., 2001, "Early Literacy Skills in African-American Children: Research Considerations," Learning Disabilities Research \& Practice, v16, n4, 213-221 